\title{
A review of the experimental evidence on the toxicokinetics of carbon monoxide: the potential role of pathophysiology among susceptible groups
}

Prabjit Barn ${ }^{1,2^{*}}$, Luisa Giles ${ }^{1,3}$, Marie-Eve Héroux ${ }^{4}$ and Tom Kosatsky ${ }^{1,2}$

\begin{abstract}
Background: Acute high level carbon monoxide (CO) exposure can cause immediate cardio-respiratory arrest in anyone, but the effects of lower level exposures in susceptible persons are less well known. The percentage of CO-bound hemoglobin in blood (carboxyhemoglobin; $\mathrm{COHb}$ ) is a marker of exposure and potential health outcomes. Indoor air quality guidelines developed by the World Health Organization and Health Canada, among others, are set so that $\mathrm{CO}$ exposure does not lead to $\mathrm{COHb}$ levels above $2.0 \%$, a target based on experimental evidence on toxicodynamic relationships between $\mathrm{COHb}$ and cardiac performance among persons with cardiovascular disease (CVD). The guidelines do not consider the role of pathophysiological influences on toxicokinetic relationships. Physiological deficits that contribute to increased CO uptake, decreased CO elimination, and increased COHb formation can alter relationships between $\mathrm{CO}$ exposures and resulting $\mathrm{COHb}$ levels, and consequently, the severity of outcomes. Following three fatalities attributed to CO in a long-term care facility (LTCF), we queried whether pathologies other than CVD could alter CO-COHb relationships. Our primary objective was to inform susceptibility-specific modeling that accounts for physiological deficits that may alter $\mathrm{CO}-\mathrm{COHb}$ relationships, ultimately to better inform $\mathrm{CO}$ management in LTCFs.

Methods: We reviewed experimental studies investigating relationships between $\mathrm{CO}, \mathrm{COHb}$, and outcomes related to health or physiological outcomes among healthy persons, persons with CVD, and six additional physiologically susceptible groups considered relevant to LTCF residents: persons with chronic obstructive pulmonary disease (COPD), anemia, cerebrovascular disease (CBD), heart failure, multiple co-morbidities, and persons of older age ( $\geq 60$ years).

Results: We identified 54 studies published since 1946. Six studies investigated toxicokinetics among healthy persons, and the remaining investigated toxicodynamics, mainly among healthy persons and persons with CVD. We identified one study each of CO dynamics in persons with COPD, anemia and persons of older age, and no studies of persons with $\mathrm{CBD}$, heart failure, or multiple co-morbidities. Considerable heterogeneity existed for exposure scenarios and outcomes investigated.

(Continued on next page)
\end{abstract}

\footnotetext{
* Correspondence: prabjit.barn@bccdc.ca

${ }^{1}$ National Collaborating Centre for Environmental Health, 200 - 601 West

Broadway, Vancouver, BC V5Z 4C2, Canada

${ }^{2}$ Environmental Health Services, British Columbia Centre for Disease Control,

655 West 12th Avenue, Vancouver, BC V5Z 4R4, Canada

Full list of author information is available at the end of the article
} 
(Continued from previous page)

Conclusions: Limited experimental human evidence on the effects of physiological deficits relevant to CO kinetics exists to support indoor air $\mathrm{CO}$ guidelines. Both experimentation and modeling are needed to assess how physiological deficits influence the $\mathrm{CO}-\mathrm{COHb}$ relationship, particularly at sub-acute exposures relevant to indoor environments. Such evidence would better inform indoor air quality guidelines and CO management in indoor settings where susceptible groups are housed.

Keywords: Carbon monoxide, Carboxyhemoglobin, Indoor air guidelines, Susceptible persons, Cardiovascular disease, Chronic obstructive pulmonary disease, Anemia

\section{Background}

Carbon monoxide is a colorless, odorless and tasteless gas produced from the incomplete combustion of carboncontaining fuels such as natural gas, oil, and wood. Common indoor sources include poorly maintained or improperly vented appliances such as furnaces, fireplaces, and gas stoves [1,2]. Tobacco smoke and vehicles left idling in attached garages or near open windows and building air intakes also contribute to indoor concentrations $[1,2]$. Intentional and unintentional indoor $\mathrm{CO}$ exposure is linked to substantial burden of disease world-wide [3-5].

Carbon monoxide toxicity is primarily mediated through hypoxic pathways, whereby $\mathrm{CO}$ molecules displace oxygen $\left(\mathrm{O}_{2}\right)$ and bind to hemoglobin to form carboxyhemolgobin $(\mathrm{COHb})[1,6]$. The concentration of $\mathrm{COHb}$ increases with concentration and duration of exposure. The increased presence of $\mathrm{COHb}$ in the blood and the resultant leftward shift in the $\mathrm{O}_{2}$ dissociation curve reduces $\mathrm{O}_{2}$ transport to and transfer at tissue sites. Other heme-containing molecules, such as myoglobin, are similarly affected $[2,7]$. Organs with the highest metabolic demand, such as the heart and brain, are most sensitive to CO-induced tissue hypoxia. Less is known about nonhypoxic pathways of $\mathrm{CO}$ toxicity [1]. Among other direct effects, $\mathrm{CO}$ has been shown to activate immunological responses by interfering with nitric oxide $(\mathrm{NO})$ production [8]. Clinical symptoms associated with the hypoxic effects of mild exposures are typically non-specific, and can include headache, nausea, and dizziness, while severe exposures, also called $\mathrm{CO}$ poisonings, can result in disorientation, unconsciousness, and cardio-respiratory arrest [1, 7]. Persons with cardiovascular (CVD) are considered most sensitive to $\mathrm{CO}$ exposure.

We undertook a review of indoor air guidelines for $\mathrm{CO}$ and their relevance to indoor settings that house susceptible persons following a $\mathrm{CO}$ poisoning incident that led to the evacuation and treatment of 24 occupants from one wing of a long-term care facility in Saskatchewan, Canada. Three of the evacuated residents died within a month of the incident. All three were elderly, with pre-existing co-morbidities, and $\mathrm{CO}$ was listed as a contributing factor in each death [9]. A power company technician was called to the facility on the morning of December 26, 2010, after several occupants reported experiencing headaches, dizziness and nausea overnight and throughout the previous day [10]. The technician measured $\mathrm{CO}$ concentrations of $63 \mathrm{ppm}$ in the affected wing, triggering an evacuation. An investigation of the facility revealed the source to be a faulty boiler that had emitted CO into the ventilation system, which was then distributed to occupied spaces in the affected wing [10]. Carbon monoxide detectors were not required in the facility at the time of the incident and there were no specific provincial or municipal regulations requiring their use. Based on the data collected by the power company technician, which may underestimate true exposures since the facility was ventilated prior to their collection, we assume that concentrations in the facility would not have triggered $\mathrm{CO}$ detectors, which are designed to alarm at $\mathrm{CO}$ levels considered to be immediately hazardous to health [11]. This incident shows the serious consequences of indoor $\mathrm{CO}$ exposure among susceptible persons, even at levels below those that may be considered immediately hazardous.

The World Health Organization (WHO) recommends that indoor air not exceed $\mathrm{CO}$ concentrations of $86 \mathrm{ppm}$, $30 \mathrm{ppm}, 9 \mathrm{ppm}$, and $6 \mathrm{ppm}$ for exposure periods of 15-min, 1-h, 8-h and 24-h, respectively. These guidelines are intended for use in settings such as homes, offices, schools, public buildings, and health care facilities [1]. Health Canada recommends that CO levels of $25 \mathrm{ppm}$ and $10 \mathrm{ppm}$ not be exceeded over periods of 1-h and 24-h, respectively, in guidelines intended for residential settings [12]. Similar methodologies were used to set WHO and Health Canada guidelines. Both guidelines are set so that short and long term exposures do not lead to $\mathrm{COHb}$ levels above $2.0 \%$. Derived from controlled human exposure studies, this maximum acceptable level is based on observed changes in exercise electrocardiograms in subjects with ischemic heart disease. Both sets of guidelines also used the Coburn-Forster-Kane (CFK) equation to model $\mathrm{CO}-\mathrm{COHb}$ relationships. This non-linear equation uses physiological parameters that influence $\mathrm{CO}$ uptake and elimination and $\mathrm{COHb}$ formation, such as the diffusing capacity of the lungs, alveolar ventilation rate, 
blood volume, and partial pressure of $\mathrm{O}_{2}$ in the pulmonary capillaries [1, 12, 13]. Health Canada's guidelines were based on an adapted CFK model that includes additional parameters to account for $\mathrm{CO}$ in alveoli and $\mathrm{CO}$-bound heme proteins in extravascular spaces [14]. All modeling scenarios were based on physiological parameters relevant to healthy adults, and as such, the setting of both WHO and Health Canada guidelines did not consider the role of physiological deficits on $\mathrm{CO}-\mathrm{COHb}$ relationships.

We hypothesized that six groups in particular may be at increased risk of adverse effects: persons with COPD, anemia, cerebrovascular disease (CBD), heart failure, multiple co-morbidities, and persons of older age $(\geq$ 60 years). COPD is characterized by lower diffusion capacity, greater alveolar dead space, and a higher degree of air trapping, all of which can decrease $\mathrm{CO}$ elimination $[1,6]$. Additionally, persons with COPD may have secondary polycythemia [15], which can increase endogenous $\mathrm{CO}$ production. Persons with anemia have lower hemoglobin concentrations, which leads to less $\mathrm{O}_{2}$ binding to hemoglobin and therefore, lower blood $\mathrm{O}_{2}$ content. Additionally, persons with hemolytic anemia have higher baseline $\mathrm{COHb}$ levels due to higher rates of endogenous $\mathrm{CO}$ production that result from increased heme catabolism $[1,6,16]$, and persons with sickle cell anemia may have increased alveolar dead space due to impaired pulmonary capillary perfusion [17]; both conditions would increase sensitivity to CO. Finally, decreased diffusing capacity, arterial degeneration and other circulatory changes among persons with heart failure, cerebrovascular (CBV) disease, persons of older age, and/or multiple co-morbidities can lead to lower baseline $\mathrm{O}_{2}$ content, and in some cases, a reduced capacity to vasodilate in response to increasing $\mathrm{CO}$ exposures $[1,6,18-$ $20]$. The objective of this review was to investigate evidence on the kinetics of $\mathrm{COHb}$ formation as a joint function of $\mathrm{CO}$ exposure and altered uptake, distribution, and elimination of $\mathrm{CO}$ and $\mathrm{O}_{2}$ in these groups, as well as in healthy persons and persons with CVD.

\section{Methods}

We reviewed experimental studies in humans investigating relationships among $\mathrm{CO}, \mathrm{COHb}$, and outcomes in healthy persons, persons with CVD, and six additional susceptible groups: persons with COPD, anemia, CBD, heart failure, multiple co-morbidities, and persons of older age ( $\geq 60$ years). Our intention was to capture all potential susceptibilities relevant to persons residing in long term care facilities. We selected susceptible groups based on (i) initial review of the rationale for indoor air quality guidelines for $\mathrm{CO}$ developed by the World Health Organization [1] and Health Canada [12], and ambient air quality criteria for $\mathrm{CO}$ developed by the U.S. Environmental Protection Agency [6], and (ii) expert consultation [21]. Our main objective was to review studies investigating $\mathrm{CO}-\mathrm{COHb}$ relationships, but to capture all relevant information, we also reviewed studies investigating $\mathrm{CO}-\mathrm{COHb}$-outcome or $\mathrm{COHb}$-outcome relationships. An outcome was considered to be any measured variable that could act as a surrogate for CO-related morbidity or mortality, including exercise duration, increases to cardiac output or heart rate, and cognitive effects. We identified articles though EBSCOhost (to access MEDLINE, CINAHL, PsycINFO, Biomedical Reference Collection, and Academic Search Complete), Ovid (to access Elsevier Science Direct, Evidence Based Medicine, SAGE journals online, and Cochrane Database of Systematic Reviews), and Google Scholar (to access books, book chapters, older articles, and articles from journals not indexed through major database platforms). We used broad keywords: "carboxyhemoglobin" or "carboxyhaemoglobin" and "carbon monoxide".

The search was restricted to English language articles using an experimental study design. No date restrictions were imposed. We reviewed abstracts of studies to exclude those involving the investigation of smoking- or occupationally-related $\mathrm{CO}$ exposures. Additional research studies were identified by reviewing article bibliographies. The search was completed in March 2017.

\section{Results}

Our search identified 2394 articles, of which 54 were retained, after the removal of duplicates, implementation of inclusion/exclusion criteria, and manual review of abstracts (Fig. 1). All of the studies were published between 1946 and 2016. Only ten studies were published since 2000, with the majority (27) having been published

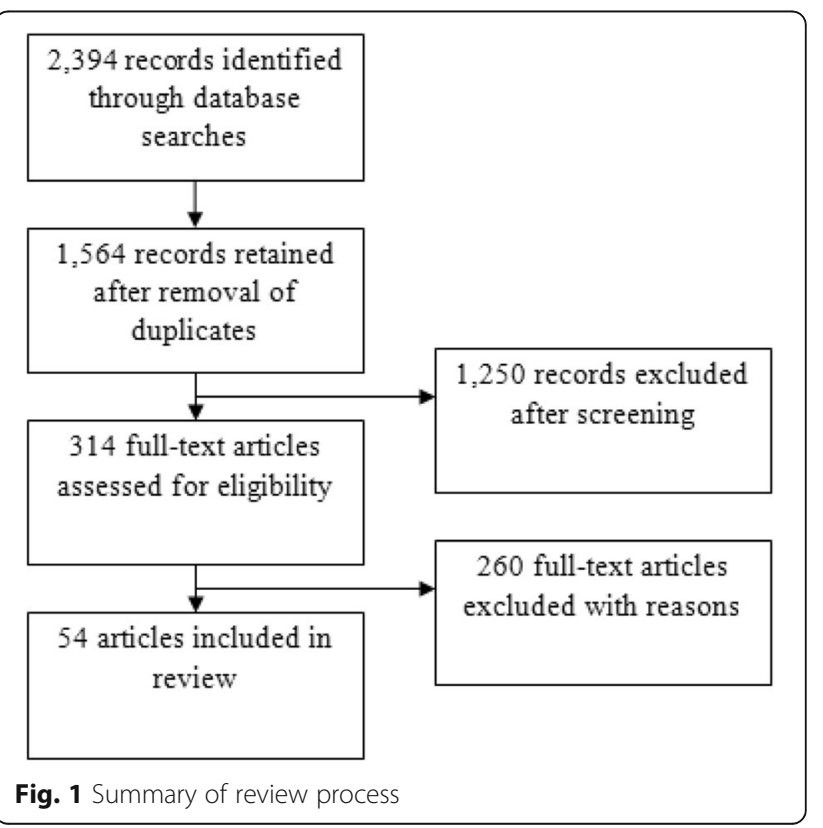


between 1970 and 1990. Most studies involved healthy adults, predominantly young males (31) [22-50], and persons with cardiovascular disease (20) [51-70]. One study was conducted among persons with COPD [71], one was conducted among persons with disease-related anemia [72], and one among healthy older persons (aged $\geq 60$ years) [73]. We found no studies conducted among persons with CBD, heart failure, or multiple co-morbidities.

Six studies investigated $\mathrm{CO}-\mathrm{COHb}$ relationships $[23$, $27,35,36,41,42]$. All of the studies were controlled exposure studies where subjects were exposed to a known $\mathrm{CO}$ concentration over a given time period, and the resulting $\mathrm{COHb}$ levels were measured during and/or after the exposure period. Exposures varied from $12 \mathrm{ppm}$ for 48 -h to $6683 \mathrm{ppm}$ for 3-7 min. All studies but one included only healthy males ranging from 20 to 42 years [23, 27, 36, 41, 42]. Hauck and Neuberger [35] included a 10-year old female subject, in addition to three male subjects aged $22-36$ years. Individual clinical and exercise-related factors that might have impacted $\mathrm{COHb}$ formation were not assessed or received little attention in all of these studies. In the earliest study, Forbes et al. [23] reported that $\mathrm{CO}$ uptake increased with physical work and duration of exposure. The remaining five studies evaluated the $\mathrm{CFK}$ equation against measured $\mathrm{COHb}$ levels [27, 35, 36, 41, 42].

Forty-nine studies investigated $\mathrm{CO}$ dynamics to understand the relationships between $\mathrm{COHb}$ concentrations and specific outcomes. One study ([36]) investigated both $\mathrm{CO}-\mathrm{COHb}$ and $\mathrm{COHb}$-outcome relationships. All but two studies used a double-blind crossover design where subjects were exposed to filtered air to establish low baseline $\mathrm{COHb}$ levels, followed by exposure scenarios corresponding to those required to reach target $\mathrm{COHb}$ levels of interest. Scenarios typically involved high exposures over short periods (e.g $7500 \mathrm{ppm}$ for $1 \mathrm{~min}$ ) or lower exposures over longer periods (e.g. $36 \mathrm{ppm}$ over $4 \mathrm{~h}$ ). In most studies, no rationale was provided for the exposure scenario or target $\mathrm{COHb}$ level of interest. Additionally, the focus of the studies was on observation of the effects of the target $\mathrm{COHb}$ levels, and no studies reported the duration of effects. Two studies used non-controlled exposures $[47,53]$. Thomassen et al. [47] exposed seven subjects sitting in a tent to $\mathrm{CO}$ generated from a camp stove. Continuous $\mathrm{CO}$ measurements were collected throughout the 2-h study period and venous blood samples were collected every $15-\mathrm{min}$. Aronow et al. [53] investigated outcomes after subjects were exposed to freeway air while sitting in a car for $2 \mathrm{~h}$; mean (standard deviation) CO concentrations were 47 (8) ppm, compared with scenarios where subjects were exposed to filtered air for $2 \mathrm{~h}$ [53].
The exposure scenarios differed greatly among the subject groups studied. Table 1 summarizes $\mathrm{CO}$ in air levels and durations, and resulting mean $\mathrm{COHb}$ levels for studies investigating toxicokinetic and toxicodynamic relationships. Differences in study design, including the exposure scenarios investigated, small sample sizes, as well as lack of reporting of baseline $\mathrm{COHb}$ levels limit comparisons of findings between studies, however, some comparisons are possible. Five studies investigated $\mathrm{CO}$ exposures of $100 \mathrm{pm} \mathrm{CO}$ for 1-h. Three of these studies were conducted among subjects with CVD $(n=24,30$, 41) $[59,63,65]$, one was conducted among healthy subjects (10) [31], and one among subjects with COPD $(n=10)$ [71]. The mean change in COHb from baseline to post-exposure was highest in a study conducted in subjects with COPD (2.6\%), compared with healthy subjects $(2.3 \%)$ and in subjects with CVD (1.5, 2.1, and $2.4 \%$ for the three studies). Additionally, two studies which were conducted among subjects with CVD $(n=$ 15) [58] and anemia [72] investigated $\mathrm{CO}$ exposures of $50 \mathrm{ppm}$ for $1-\mathrm{h},(\mathrm{n}=10)$. The mean change in $\mathrm{COHb}$ was higher in the study conducted in subjects with anemia (1.2\%) compared with that conducted in subjects with CVD (0.9\%).

The outcome measures studied also varied by clinical population. In healthy subjects, outcome measures included exercise performance, cardiac function (e.g. changes to cardiac output, heart rate, and electrocardiogram tests), respiratory response (e.g. lung capacity, minute ventilation), and nervous system response (e.g. cognitive function, behavioral impairments). For subjects with CVD, the most commonly assessed outcome was exercise-induced angina. Exercise performance was the only outcome investigated in subjects with COPD and anemia, and cognitive function was the only outcome investigated in older persons (Table 2). The lowest level for which any effect was observed was at $2 \%$. At this level, a decrease in mean length of time to a threshold ischemic ST-segment change and decreased time to onset of angina was observed among persons with ischemic heart disease. The relationship between $\mathrm{COHb}$ levels $>2 \% \mathrm{COHb}$ and outcomes were investigated for our additional groups of interest.

\section{Discussion}

We reviewed evidence from 54 peer-reviewed experimental studies in humans investigating relationships between $\mathrm{CO}$ concentrations in air, $\mathrm{COHb}$ levels, and outcomes among healthy persons, those with CVD, and an additional six susceptible groups. Few studies have investigated the toxicokinetics of $\mathrm{CO}$. Only six of the 54 studies identified in our search measured the relationship between $\mathrm{CO}$ exposure and $\mathrm{COHb}$ formation, and all six involved healthy participants. Since the objective of five of the six studies was to compare $\mathrm{COHb}$ levels 
Table 1 Summary of carbon monoxide (CO) exposure levels and durations and corresponding carboxyhemoglobin (COHb) levels, by health status

\begin{tabular}{|c|c|c|c|c|c|}
\hline Exposure period & $\begin{array}{l}\text { Exposure } \\
\text { level (ppm) }\end{array}$ & $\begin{array}{l}\text { Number } \\
\text { of subjects }\end{array}$ & $\begin{array}{l}\text { Mean }{ }^{\mathrm{a}} \mathrm{COHb}(\%) \text { among } \\
\text { controls or during control } \\
\text { period }^{\mathrm{b}}\end{array}$ & $\begin{array}{l}\text { Mean }{ }^{\mathrm{a}} \mathrm{COHb}(\%) \text { among exposed } \\
\text { persons or after exposure }\end{array}$ & $\begin{array}{l}\text { Mean increase in } \mathrm{COHb} \\
\text { with exposure }{ }^{c}(\%)\end{array}$ \\
\hline \multicolumn{6}{|l|}{ Healthy subjects } \\
\hline $\begin{array}{l}1 \text { min ( } 5 \text { exposures separated by } \\
7 \text { min each) [36] }\end{array}$ & 7500 & 11 & $N R$ & $N R$ & 2.05 \\
\hline $3-6.65 \min [42]$ & 6683 ppm & 15 & 2.08 (SD: 0.08) & $N R$ & - \\
\hline $2.5-3.5 \min [25]$ & $5000^{d}$ & 10 & NR & 3.95 (SD: 1.87) & - \\
\hline $\begin{array}{l}5 \min (\times 5 \text { exposures separated } \\
\text { by } 3 \text { min each) [36] }\end{array}$ & 1500 & 11 & $N R$ & $N R$ & 2.08 \\
\hline $3-8 \min [50]$ & $3000^{d}$ & 12 & $N R$ & 6.2 (SD: 0.3) & - \\
\hline $10-30 \min [45]$ & 4000 & 12 & $N R$ & 10 & - \\
\hline $30 \min [49]$ & $500^{d}$ & 15 & 1.2 (SD: 0.5) & 8.5 (SD: 0.9) & 7.3 \\
\hline $30-45 \min [46]$ & 1200 & 10 & - & 10 & - \\
\hline \multirow[t]{3}{*}{$1 \mathrm{~h}$} & $100[31]^{d}$ & 10 & 1.67 (SD: 0.33) & 3.95 (SD: 0.49) & 2.28 \\
\hline & $500[49]^{d}$ & 15 & 1.2 (SD: 0.5) & 9.4 (SD: 0.6) & 8.2 \\
\hline & $500[48]$ & 13 & $1.2(95 \% \mathrm{Cl}: 1.0,1.4)$ & 7.0 (95\% Cl: $6.5,7.7)$ & 5.8 \\
\hline \multirow[t]{2}{*}{$4 \mathrm{~h}[34]$} & 35.7 & 30 & 1.5 (SD: 0.27) & 3.03 (SD: 0.71) & 1.53 \\
\hline & 74.1 & 30 & 1.3 (SD: 0.39) & 5.1 (SD: 0.57) & 3.80 \\
\hline \multirow[t]{2}{*}{10 days [33] } & $15^{\mathrm{d}}$ & 15 & 0.5 & 2.4 & 1.90 \\
\hline & $50^{d}$ & 15 & 0.5 & 7.2 & 6.70 \\
\hline \multicolumn{6}{|l|}{ Susceptible groups } \\
\hline \multicolumn{6}{|l|}{ Subjects with cardiovascular disease } \\
\hline $3-120$ s [51] & 50,000 & 25 & 0.98 & 8.96 & 7.98 \\
\hline \multirow[t]{2}{*}{$50-70 \min [61]$} & $117(S D: 4.4)^{d}$ & 63 & 0.6 (SD: 0.02) & 2.0 (SD: 0.05) & 1.4 \\
\hline & $253(\text { SD: } 6.1)^{\mathrm{d}}$ & 63 & 0.6 (SD: 0.02) & 3.9 (SD: 0.08) & 3.3 \\
\hline \multirow[t]{7}{*}{$1 \mathrm{~h}$} & $50[58]^{d}$ & 15 & 1.09 (SD: 0.15) & 2.02 (SD: 0.16) & 0.93 \\
\hline & $100[63]^{d}$ & 24 & 1.5 & 3 & 1.5 \\
\hline & $100[65]^{d}$ & $41 c$ & 1.82 (SD: 0.06) & 3.93 (SD: 0.07) & 2.11 \\
\hline & $100[59]^{d}$ & $30 \mathrm{c}$ & 1.7 & 4.1 & 2.4 \\
\hline & 159 (SD: 25) [68] ${ }^{d}$ & $33 \mathrm{c}$ & 0.7 & 3.2 & 2.5 \\
\hline & $200[64]^{d}$ & 41 & 1.82 (SD: 0.06) & 5.91 (SD: 0.07) & 4.09 \\
\hline & $292(\text { SD: 31) [68] }]^{d}$ & $33 c$ & 0.7 & 5.1 & 4.4 \\
\hline \multirow[t]{2}{*}{$1.5 \mathrm{~h}$} & $53(S D: 6)[53]^{d}$ & 10 & 1.12 (SD: 1.20) & 5.08 (SD: 1.19) & 3.96 \\
\hline & $100[69]^{d}$ & 17 & $0.2-2.1$ & $4.2(\mathrm{SD}: 0.3)$ & - \\
\hline \multirow[t]{4}{*}{$2 \mathrm{~h}$} & $50[55]^{d}$ & $10 \mathrm{c}$ & $1.03(0.27)$ & 2.68 (SD: 0.15) & 1.65 \\
\hline & $50[56]^{d}$ & 10 & 1.08 & 2.77 & 1.69 \\
\hline & $100[69]^{d}$ & 17 & 0.64 & 3.91 & 3.27 \\
\hline & 142 ppm [39] & 21 & 0.80 (SD: 0.20$)$ & 17.06 (SD: 1.38) & \\
\hline \multirow[t]{2}{*}{$4 \mathrm{~h}[54]$} & $50^{d}$ & 10 & 1.3 & 2.9 (range: $1.3-3.8$ ) & 1.6 \\
\hline & $100^{d}$ & 10 & 1.3 & 4.5 (range: $2.8-5.4$ ) & 3.2 \\
\hline \multicolumn{6}{|c|}{ Subjects with chronic obstructive pulmonary disease } \\
\hline $1 \mathrm{~h}[71]^{\mathrm{d}}$ & 100 & 10 & 1.48 & 4.08 & 2.60 \\
\hline \multicolumn{6}{|l|}{ Subjects with anaemia } \\
\hline $1 \mathrm{~h}[72]$ & $50^{d}$ & 10 & 2.14 (SD: 0.55) & 3.38 (SD: 0.83) & 1.24 \\
\hline \multicolumn{6}{|l|}{ Subjects of older age (> 60 years) } \\
\hline 3 h [73] & 50 & 36 & 1.30 & 2.77 & 1.47 \\
\hline
\end{tabular}

${ }^{a}$ Additional summary statistics provided where reported, including standard deviation (SD), range, and 95\% confidence intervals (Cl). COHb levels reported to the number of

decimal points reported in the original paper
${ }^{\mathrm{b}}$ Represents $\mathrm{COHb}$ levels after exposure to fresh/filtered air, or pre-CO exposure; NR $=$ not reported

${ }^{C}$ Calculated as difference between pre (baseline) and post exposure $\mathrm{COHb}$ levels where values were reported. Dashed line (--) indicates that not enough information was available for calculation. The number of decimal points are presented to match values reported in the original paper

dExperimental conditions included exercise 
Table 2 Summary of lowest levels of carboxyhemoglobin (COHb) for which health outcomes have been described, by health status

\begin{tabular}{|c|c|c|c|}
\hline Health outcome & $\begin{array}{l}\text { Lowest mean } \\
\text { cOHb for measured response }{ }^{a}(\%)\end{array}$ & $\begin{array}{l}\text { Associated } \mathrm{CO} \\
\text { exposure }\end{array}$ & Response \\
\hline \multicolumn{4}{|l|}{ Healthy subjects } \\
\hline Exercise-induced arrhythmias [44] & $5[44]$ & $\begin{array}{l}1000-3000 \mathrm{ppm} \\
\text { for } 4-6 \mathrm{~min}\end{array}$ & No effect. \\
\hline Exercise duration $[31,32,40,50]$ & 3.95 (SD: 0.49) [31] & $100 \mathrm{ppm}$ for $1 \mathrm{~h}$ & $\begin{array}{l}\text { Decrease in mean exercise duration from } 698 \\
\text { to } 663 s(p<0.001) \text {. }\end{array}$ \\
\hline $\begin{array}{l}\text { Cardiovascular effects (cardiac output, heart } \\
\text { rate, artery diameter, electrocardiogram } \\
\text { changes) }[25,29,33,49,89,90]\end{array}$ & $2.4[33]$ & $\begin{array}{l}15 \text { ppm for } \\
10 \text { days } \\
\text { (continuous } \\
\text { exposure) }\end{array}$ & $\begin{array}{l}\text { Electrocardiogram changes, specifically to } \\
\text { p-waves, observed among three out of } 15 \\
\text { subjects. }\end{array}$ \\
\hline Respiratory effects $[22,25,36,45,46,89,91]$ & 3.95 (SD: 1.87) [25] & $\begin{array}{l}5000 \mathrm{ppm} \text { for } \\
2.5-3.5 \mathrm{~min}\end{array}$ & $\begin{array}{l}\text { Decrease in mean }(\mathrm{sd}) \text { inspiratory capacity from } \\
3655(415) \mathrm{ml} \text { to } 3380(419) \mathrm{ml}(p<0.05) \text {, and } \\
\text { total lung capacity from } 7705(1083) \mathrm{ml} \text { to } \\
7545 \text { (993) } \mathrm{ml}(p<0.02) \text {. }\end{array}$ \\
\hline Cognitive function $[24,26,28,34,37,38,43,47]$ & 5.1 (SD: 0.57) [34] & $\begin{array}{l}74.1 \mathrm{ppm} \text { for } \\
4 \mathrm{~h}\end{array}$ & $\begin{array}{l}\text { Decreases in performance of visual tracking } \\
\text { exercises among high exposure group, } \\
\text { compared with low exposure and control } \\
\text { groups }(p<0.01) \text {. }\end{array}$ \\
\hline Cytokine production [48] & 7 (95\% Cl: 6.5,7.7) [48] & 500 ppm for $1 \mathrm{~h}$ & No effect. \\
\hline Visual function [39] & 17.06 (SD: 1.38) [39] & $\begin{array}{l}11,569 \mathrm{ppm} \text { for } \\
4-5 \mathrm{~min}, \\
\text { followed by } \\
141 \text { ppm for } 2 \mathrm{~h}\end{array}$ & No effect. \\
\hline
\end{tabular}

Susceptible groups

Subjects with cardiovascular disease

Exercise-induced angina [53-55, 58-63, 66, 70] 2.0 (SD: 0.05) [61]

Exercise-induced arrhythmias [54, 61, 64, 5.91 (SD: 0.07) [65] $65,67-69]$

Other cardiovascular effects [51, 52, 61, 66, 69] 2.0 (SD: 0.05) [61]

Cognitive function [57]

$3.90[57]$

Exercise-induced claudication (impairment, 2.77 [56] pain discomfort in legs) [56]

Subjects with chronic obstructive pulmonary disease

Exercise performance [71]

4.08 [71]

Subjects with anemia

Exercise performance [72]

3.38 (SD: 0.83) [72]

Subjects of older age (> 60 years)

Cognitive function [73]

$5.0[73]$
$117 \mathrm{ppm}$ for 50-70 min

Decrease in mean (sd) time to onset of angina from 501 (25) seconds to 482 (22) seconds $(p=0.054)$.

200 ppm for $1 \mathrm{~h}$ Higher frequency of single premature ventricular contractions per hour during exercise among subjects $(p=0.03)$.

$117 \mathrm{ppm}$ for Decrease in mean (sd) length of time to a 50-70 min threshold ischemic ST-segment change from 576 (27) seconds to 510 (26) seconds $(p<0.0001)$.

$100 \mathrm{ppm}, \quad$ Decrease in mean performance of visualization duration not test $(p<0.001)$, but no effects on performance reported of speed, flexibility, digit symbol, time perception, or reaction time tests.

$50 \mathrm{ppm}$ for $2 \mathrm{~h}$ Decrease in mean (sd) exercise time until onset of intermittent claudication from 174 (49) to 144 (38) seconds.

$100 \mathrm{ppm}$ for $1 \mathrm{~h}$ Decrease in mean $(\mathrm{sd})$ exercise duration from 219 (48) to 147 (28) seconds $(p<0.001)$.

$50 \mathrm{ppm}$ for $1 \mathrm{~h}$ Decrease in mean (sd) exercise duration from 221 (72) to 217 (73) seconds $(p<0.0001)$.

200 ppm for $1 \mathrm{~h}$ No effect. and $50 \mathrm{ppm}$ for

$2 \mathrm{~h}$

${ }^{a}$ Additional summary statistics provided where reported, including standard deviation (SD), range, and 95\% confidence intervals (CI) 
predicted by the CFK model with measured levels following controlled exposures, few physiological parameters important to $\mathrm{CO}-\mathrm{COHb}$ relationships were investigated. As for toxicodynamic studies, limited between-study comparison of $\mathrm{CO}-\mathrm{COHb}$ levels is possible, taking into account pathophysiology. A higher mean increase in $\mathrm{COHb}$ from baseline to post-exposure was reported in a study of persons with COPD, compared with four studies of healthy persons or persons with CVD, at an equivalent $\mathrm{CO}$ exposure of $100 \mathrm{ppm}$ for 1-h. Similarly, a higher mean increase in $\mathrm{COHb}$ was reported in a study of persons with anemia compared with a study of persons with CVD, at an equivalent $\mathrm{CO}$ exposure of $50 \mathrm{ppm}$ for 1-h. Although findings from these studies cannot be directly compared for several reasons, including differing baseline $\mathrm{COHb}$ levels, the lack of subject-level data, and small sample sizes, the limited evidence does suggest that higher $\mathrm{COHb}$ levels may occur among some groups, likely due to underlying pathology, compared with healthy persons (or persons with CVD) at equivalent $\mathrm{CO}$ exposures. As we hypothesized, specific physiological deficits such as increased air trapping and greater alveolar dead space may increase $\mathrm{CO}$ absorption, decrease $\mathrm{CO}$ elimination, and/or increase $\mathrm{COHb}$ formation. Currently, WHO and Health Canada do not consider differences in toxicokinetics between susceptible groups in setting $\mathrm{CO}$ guidelines for indoor air, and instead assume that $\mathrm{CO}-\mathrm{COHb}$ relationships estimated based on parameters reflecting those of healthy adults are representative of the entire population. These limited findings suggest that this may not be the case, and highlight the need for more evidence on $\mathrm{CO}-\mathrm{COHb}$ relationships in susceptible groups.

Although experimental studies can allow for direct measure of $\mathrm{CO}-\mathrm{COHb}$ relationships, there are limitations to the evidence these studies can provide. It is unethical to expose people to harmful CO levels, particularly over long periods of time. Additionally, it may not be appropriate to extrapolate findings on acute exposures to guidelines intended to protect persons from the effects of longerterm $\mathrm{CO}$ exposures, such as those intended for 24-h periods. An alternative to experimentation is the use of models that predict $\mathrm{CO}-\mathrm{COHb}$ relationships. The use of models based on physiological deficits relevant to this relationship over a range of exposure scenarios can allow for a fuller understanding of CO-related susceptibility. Several empirical and mechanistic models have been developed to estimate the uptake and distribution of $\mathrm{CO}$ [74], including the widely used CFK equation [13, 75]. Other researchers have adapted the CFK equation to include additional physiological parameters in an attempt to more precisely predict $\mathrm{CO}-\mathrm{COHb}$ relationships. An example is the setting Health Canada guidelines, which use an adapted CFK equation that incorporates parameters to account for $\mathrm{CO}$ in alveoli and CO-bound heme proteins in extravascular spaces [14]. Fewer studies, however, have attempted to model the effects of specific physiological deficits on $\mathrm{CO}-\mathrm{COHb}$ relationships [76]. Benignus and Coleman 2010 [76] used a whole-body physiological model, which uses a form of the CFK equation, to simulate effects of $\mathrm{CO}$ on exercise duration among healthy persons and those with vascular disease at different exercise levels. Stenosis of the left heart arterial supply was introduced to simulate IHD, and stenosis of the cerebral arteries to simulate reductions in brain flow. For simulations involving IHD, the authors reported that the largest reductions in exercise duration were seen with the lowest severity of ischemia and $\mathrm{COHb}$ concentrations. For simulations involving reduced brain blood flow, a non-threshold effect on brain metabolism was seen for any increase in $\mathrm{COHb}$ levels when blood flow was reduced by more than $50 \%$. In their Qualitative Risk and Exposure Assessment for Carbon Monoxide [77], the U.S. EPA used the CFK equation to model $\mathrm{COHb}$ levels in a simulated urban population with coronary heart disease. The population was assumed to be exposed to $\mathrm{CO}$ concentrations equivalent to the 8-h ambient $\mathrm{CO}$ standard of $9 \mathrm{ppm}$. The $\mathrm{COHb}$ levels in this population were estimated using a haemoglobin distribution relevant to the general population as well as an "anemic haemoglobin distribution" that was reflective of persons with anemia [77]. The percentage of the population with daily maximum $\mathrm{COHb}$ levels at or above $2 \%$ increased from $5.3 \%$ to $8.2 \%$ when the anemic haemoglobin distribution was used [77]. Modelling exercises such as these can be used to provide an understanding of how various sub-populations are affected under different $\mathrm{CO}$ exposure scenarios, which would not be possible with experimentation alone. Epidemiologic evidence can also inform our understanding of $\mathrm{CO}$ on susceptible persons, but must be interpreted with caution. Limited evidence suggests associations between 1 and 6 day ambient $\mathrm{CO}$ concentrations and increased emergency admissions for persons with COPD and sickle cell anemia [78-81]. However, recent studies have also suggested that low level ambient $\mathrm{CO}$ exposures, typically below $5 \mathrm{ppm}$, may be protective of some respiratory effects [82, 83]. More research is needed to assess how sub-acute and chronic $\mathrm{CO}$ exposures may affect these groups, including the mechanisms underlying these effects.

The majority of the studies (92\%) we accessed attempted to characterize $\mathrm{COHb}$-outcome relationships, predominantly among healthy persons. It is well characterized that the lowest $\mathrm{COHb}$ level at which an effect is seen is $2 \%$. However, the degree to which severity of disease impacts this relationship has not been investigated. Additionally, equivalent sensitive outcomes, such as changes in ECG readings, have not been investigated in groups outside of those with CVD, making it difficult to compare $\mathrm{CO}$ sensitivity between potentially susceptible 
groups. The lack of data on $\mathrm{CO}$ effects among persons with multiple co-morbidities is also important, considering that individuals may have several conditions that potentially increase their overall susceptibility to $\mathrm{CO}$. For example, persons with COPD are also likely to have CVD [84] and to a lesser degree, anemia [85]. The existing literature is also limited in other ways. While many studies reported mean $\mathrm{COHb}$ levels before and after $\mathrm{CO}$ exposures among all study subjects, few provided statistics on the distribution of $\mathrm{COHb}$ levels, including standard deviations around the mean, ranges, or subjectspecific data. As noted earlier, study subjects consisted mainly of young healthy males, and where female and/or older subjects were included, reporting of results was insufficient to allow for examination of the role of sex or age on $\mathrm{COHb}$-outcome relationships. Finally, much of the existing literature was published over 20 years ago. Improvements in measurement techniques have most likely led to more accurate $\mathrm{CO}$ and $\mathrm{COHb}$ measurements over time, and values reported in older studies are likely less reliable.

This review was conducted following a $\mathrm{CO}$ incident that was associated with three deaths in a long term care facility. Provincial or municipal regulations requiring $\mathrm{CO}$ detectors in Canadian health care facilities did not exist at the time of the incident. $\mathrm{CO}$ detector use has been shown to reduce $\mathrm{CO}$ poisonings in homes [86-88], and extending their use to other indoor settings would be beneficial, particularly where susceptible occupants are housed. However, CO detectors are only intended to prevent acute exposures at levels judged immediately hazardous to health, and therefore, it would be advantageous to consider ways to prevent low level exposures through comprehensive $\mathrm{CO}$ management programs based on education, prevention, and monitoring. In Canada as elsewhere, certified CO detectors are approved to alarm at levels considerably higher than those recommended by indoor air guidelines. Alarms are triggered when a peak value of $400 \mathrm{ppm}$ is reached within 4-15 min, $150 \mathrm{ppm}$ is reached within $15-50 \mathrm{~min}$ and when approximately $70 \mathrm{ppm}$ is reached within $1-4 \mathrm{~h}$ [11]. These values are considered equivalent to an attained $10 \% \mathrm{COHb}$ level, which is considerably higher than the $2 \%$ level used to derive guideline values. Certification and use of more sensitive detectors that both display and alarm at $\mathrm{CO}$ concentrations in the lower range would allow for better protection of the health of susceptible occupants.

\section{Conclusions}

Our review of the experimental literature found that few studies have examined $\mathrm{CO}-\mathrm{COHb}$ relationships, and in general, persons with COPD, anemia, CBD, heart failure, persons of older age, as well as those with multiple co- morbidities have largely been overlooked in the experimental $\mathrm{CO}$ research. Indoor air guidelines, which are largely based on limited experimental research on $\mathrm{CO}$ toxicodynamics, do not take into account the potential impacts of physiological deficits that alter $\mathrm{CO}$ uptake and elimination as well as $\mathrm{COHb}$ formation. Susceptibility-specific toxicokinetic modelling is needed to better understand how $\mathrm{CO}-\mathrm{COHb}$ relationships differ among susceptible groups. This information in turn, can better inform indoor air guidelines as well as CO management practices in indoor settings where susceptible persons are housed.

\section{Abbreviations \\ CBD: Cerebrovascular disease; CFK: Coburn-Forster-Kane; CO: Carbon monoxide; COHb: Carboxyhemologbin; COPD: Chronic obstructive pulmonary disease; CVD: Cardiovascular disease; IHD: Ischemic heart disease; $\mathrm{O}_{2}$ : Oxygen; WHO: World Health Organization}

\section{Acknowledgments}

We would like to thank Michele Wiens (National Collaborating Centre for Environmental Health) for leading our literature search, as well as Erna van Balen (previously with National Collaborating Centre for Environmental Health) for helping us with the initial stages of the review.

\section{Availability of data and supporting material sections}

Data sharing not applicable to this article as no datasets were generated for this review.

\section{Funding \\ This work was funded by the Water, Air, and Climate Change Bureau, Health Canada (contract number 4500325958).}

\section{Authors' contributions}

All authors conceived of the paper and contributed to its development and writing, and approved the final manuscript.

Ethics approval and consent to participate

Not applicable.

Consent for publication

Not applicable.

Competing interests

The authors declare that they have no competing interests.

\section{Publisher's Note}

Springer Nature remains neutral with regard to jurisdictional claims in published maps and institutional affiliations.

\begin{abstract}
Author details
${ }^{1}$ National Collaborating Centre for Environmental Health, 200 - 601 West Broadway, Vancouver, BC V5Z 4C2, Canada. ${ }^{2}$ Environmental Health Services, British Columbia Centre for Disease Control, 655 West 12th Avenue, Vancouver, BC V5Z 4R4, Canada. ${ }^{3}$ Currently at: Department of Sport Science, Douglas College, P.O. Box 2503, 700 Royal Avenue, New Westminster, BC V3L 5B2, Canada. ${ }^{4}$ Water and Air Quality Bureau, Health Canada, 269 Laurier Ave West, Ottawa K1A OK9, Canada.
\end{abstract}

Received: 30 March 2017 Accepted: 26 January 2018

Published online: 05 February 2018

References

1. World Health Organization. WHO guidelines for indoor air quality: selected pollutants. Geneva: WHO; 2010. http://www.euro.who.int/_data/assets/pdf_ file/0009/128169/e94535.pdf. 
2. Raub JA, Mathieu-Nolf M, Hampson NB, Thom SR. Carbon monoxide poisoning - a public health perspective. Toxicology. 2000;145(1):1-14. https://doi.org/10.1016/s0300-483x(99)00217-6.

3. Lavigne E, Weichenthal S, Wong J, Smith-Doiron M, Dugandzic R, Kosatsky T. Mortality and hospital admission rates for unintentional nonfire-related carbon monoxide poisoning across Canada: a trend analysis. CMAJ Open. 2015;3(2):E223-30. https://doi.org/10.9778/cmajo.20140122.

4. Braubach M, Algoet A, Beaton M, Lauriou S, Heroux ME, Krzyzanowski M. Mortality associated with exposure to carbon monoxide in WHO European member states. Indoor Air. 2013;23(2):115-25. https://doi.org/10.1111/ina. 12007.

5. Bronstein A, Clower JH, lqbal S, Yip FY, Martin CA, Chang A, Wolkin AF, Bell J. Carbon monoxide exposures, United States, 2000-2009. Mor Mortal Wkly Rep CDC Surveill Summ. 2011;60(30):1014-7.

6. U.S. Environmental Protection Agency. Air quality criteria for carbon monoxide. 2000. https:/cfpub.epa.gov/ncea/risk/recordisplay.cfm?deid=18163.

7. Agency for Toxic Substances and Drug Registry. Toxicological profile for carbon monoxide. Atlanta, GA: U.S. Department of Health and Human Services: 2012. https:/www.atsdr.cdc.gov/toxprofiles/tp.asp?id=1145\&tid=253

8. Rose JJ, Wang L, McTiernan C, Shiva C, Tejero J, Gladwin M. Carbon monoxide poisoning: pathogenesis, management, and future directions of therapy. Am J Respir Crit Care Med. 2017;195(5):596-606. https://doi.org/10. 1164/rccm.201606-1275Cl.

10. Saskatoon Health Region. Review of carbon monoxide exposure in St Mary's Villa long term care facility Humboldt, Saskatchewan, December 26, 2010. Regina, SK: Saskatoon Health Region; 2011.

9. Saskatoon Health Region. Epidemiological analysis of residents of St. Mary's Villa, Humboldt, October 3-2010 - February 26, 2011. Regina, SK: Saskatoon Health Region; 2011.

11. Canadian Standards Association. CSA 6.19-01. Residential carbon monoxide alarming devices. 2001.

12. Health Canada. Residential indoor air quality guideline: carbon monoxide. Ottawa, ON: Health Canada; 2010. http://www.hc-sc.gc.ca/ewh-semt/pubs/ air/carbon_mono/index-eng.php.

13. Coburn RF, Forster RE, Kane PB. Considerations of the physiological variables that determine the blood carboxyhemoglobin concentration in man. J Clin Invest. 1965;44(11):1899-910.

14. Gosselin NH, Brunet RC, Carrier G. Determination of carboxyhaemoglobin in humans following low-level exposures to carbon monoxide. Inhal Toxicol. 2009;21(13):1077-91. https://doi.org/10.3109/08958370902744848.

15. Kent BD, Mitchell PD, McNicholas WT. Hypoxemia in patients with COPD: cause, effects, and disease progression. Int J Chronic Obstr. 2011;6:199-208. https://doi.org/10.2147/COPD.S10611.

16. Sears DA, Udden MM, Thomas LJ. Carboxyhemoglobin levels in patients with sickle-cell anemia: relationship to hemolytic and vasoocclusive severity. Am J Med Sci. 2001;322(6):345-8.

17. Pianosi P, D'Souza SJ, Esseltine DW, Charge TD, Coates AL. Ventilation and gas exchange during exercise in sickle cell anemia. Am Rev Respir Dis. 1991; 143(2):226-30.

18. Strait JB, Lakatta EG. Aging-associated cardiovascular changes and their relationship to heart failure. Heart Fail Clin. 2012;8(1):143-64. https://doi.org/ 10.1016/j.hfc.2011.08.011

19. Morosin M, Vignati C, Novi A, Salvioni E, Veglia F, Alimento M, Merli G, Sciomer S, Sinagra G, Agostoni P. The alveolar to arterial oxygen partial pressure difference is associated with pulmonary diffusing capacity in heart failure patients. Respir Physiol Neurobiol. 2016;233:1-6. https://doi.org/10. 1016/j.resp.2016.06.004.

20. Kee KK. Increased dead space ventilation mediates reduced exercise capacity in systolic heart failure. Am J Respir Crit Care Med. 2016;193(11): 1292-300. https://doi.org/10.1164/rccm.201508-15550C.

21. National Collaborating Centre for Environmental Health. Carbon monoxide monitoring in long term care facilities and hospitals. Carbon Monoxide Monitoring in Long Term Care Facilities and Hospitals: Experts Group Meeting. Vancouver, BC: National Collaborating Centre for Environmental Health; 2013. http://www.ncceh.ca/content/carbon-monoxide-monitoringlong-term-care-facilities-and-hospitals. Accessed 20 Feb 2017

22. Pitts GC, Pace N. The effect of blood carboxyhemoglobin concentration on hypoxia tolerance. Am J Phys. 1947;148(1):139-51.

23. Forbes $W$, Sargent F, Roughton F. The rate of carbon monoxide uptake by normal men. Am J Phys. 1945;143(4):594-608.

24. Schulte $\mathrm{JH}$. Effects of mild carbon monoxide intoxication. Arch Environ Health. 1963;7:524-30.
25. Chevalier RB, Krumholz RA, Ross JC. Reaction of nonsmokers to carbon monoxide inhalation. Cardiopulmonary responses at rest and during exercise. JAMA. 1966;198(10):1061-4.

26. Beard RR, Wertheim GA. Behavioral impairment associated with small doses of carbon monoxide. Am J Public Health Nations Health. 1967;57(1 1):2012-22.

27. Peterson JE, Stewart RD. Absorption and elimination of carbon monoxide by inactive young men. Arch Environ Health. 1970;21(2):165-71.

28. Stewart RD, Peterson JE, Baretta ED, Bachand RT, Hosko MJ, Herrmann AA Experimental human exposure to carbon monoxide. Arch Environ Health. 1970;21(2):154-64.

29. Parving $\mathrm{HH}$. The effect of hypoxia and carbon monoxide exposure on plasma volume and capillary permeability to albumin. Scand J Clin Lab Invest. 1972;30(1):49-56

30. Vogel JA, Gleser MA, Wheeler RC, Whitten BK. Carbon monoxide and physical work capacity. Arch Environ Health. 1972;24(3):198-203.

31. Aronow WS, Cassidy J. Effect of carbon monoxide on maximal treadmill exercise. A study in normal persons. Ann Intern Med. 1975:83(4):496-9.

32. Horvath SM, Raven PB, Dahms TE, Gray DJ. Maximal aerobic capacity at different levels of carboxyhemoglobin. J Appl Physiol. 1975;38(2):300-3.

33. Davies DM, Smith DJ. Electrocardiographic changes in healthy men during continuous low-level carbon monoxide exposure. Environ Res. 1979;21(1): 197-206. https://doi.org/10.1016/0013-9351(80)90022-5.

34. Putz VR. The effects of carbon monoxide on dual-task performance. Hum Factors. 1979;21(1):13-24.

35. Hauck H, Neuberger M. Carbon monoxide uptake and the resulting carboxyhemoglobin in man. Eur J Appl Physiol. 1984;53(2):186-90.

36. Tikuisis P, Buick F, Kane DM. Percent carboxyhemoglobin in resting humans exposed repeatedly to 1,500 and 7,500 ppm CO. J Appl Physiol. 1987;63(2):820-7.

37. Bunnell DE, Horvath SM. Interactive effects of physical work and carbon monoxide on cognitive task performance. Aviat Space Environ Med. 1988; 59(12):1133-8.

38. Bunnell DE, Horvath SM. Interactive effects of heat, physical work, and CO exposure on metabolism and cognitive task performance. Aviat Space Environ Med. 1989;60(5):428-32.

39. Hudnell HK, Benignus VA. Carbon monoxide exposure and human visual detection thresholds. Neurotoxicol Teratol. 1989;11(4):363-71.

40. Adir Y, Merdler A, Ben Haim S, Front A, Harduf R, Bitterman H. Effects of exposure to low concentrations of carbon monoxide on exercise performance and myocardial perfusion in young healthy men. Occup Environ Med. 1999:56(8):535-8.

41. Tikuisis $P$, Kane DM, McLellan TM, Buick F, Fairburn SM. Rate of formation of carboxyhemoglobin in exercising humans exposed to carbon monoxide. J Appl Physiol. 1992;72(4):1311-9.

42. Benignus VA, Hazucha MJ, Smith MV, Bromberg PA. Prediction of carboxyhemoglobin formation due to transient exposure to carbon monoxide. J Appl Physiol. 1994;76(4):1739-45.

43. Amitai Y, Zlotogorski Z, Golan-Katzav V, Wexler A, Gross D. Neuropsychological impairment from acute low-level exposure to carbon monoxide. Arch Neurol. 1998;55(6):845-8.

44. Kizakevich PN, McCartney ML, Hazucha MJ, Sleet LH, Jochem WJ, Hackney AC, Bolick K. Noninvasive ambulatory assessment of cardiac function in healthy men exposed to carbon monoxide during upper and lower body exercise. Eur J Appl Physiol. 2000;83(1):7-16. https://doi.org/10.1007/ s004210000256

45. Ren X, Dorrington KL, Robbins PA. Respiratory control in humans after $8 \mathrm{~h}$ of lowered arterial PO2, hemodilution, or carboxyhemoglobinemia. J Appl Physiol. 2001;90(4):1189-95.

46. Vesely AE, Somogyi RB, Sasano H, Sasano N, Fisher JA, Duffin J. The effects of carbon monoxide on respiratory chemoreflexes in humans. Environ Res. 2004;94(3):227-33. https://doi.org/10.1016/s0013-9351(03)00107-5.

47. Thomassen O, Brattebo G, Rostrup M. Carbon monoxide poisoning while using a small cooking stove in a tent. Am J Emerg Med 2004, 22(3):204-206. doi: S0735675704000476.

48. Mayr FB, Spiel A, Leitner J, Marsik C, Germann P, Ullrich R, Wagner O, Jilma $B$. Effects of carbon monoxide inhalation during experimental endotoxemia in humans. Am J Respir Crit Care Med. 2005;171(4):354-60.

49. Resch H, Zawinka C, Weigert G, Schmetterer L, Garhofer G. Inhaled carbon monoxide increases retinal and choroidal blood flow in healthy humans. Invest Ophthalmol Vis Sci. 2005:46(11):4275-80. https://doi.org/10.1167/iovs. 05-0417. 
50. Morse Cl, Pritchard LJ, Wust RC, Jones DA, Degens H. Carbon monoxide inhalation reduces skeletal muscle fatigue resistance. Acta Physiol (Oxf). 2008;192(3):397-401. https://doi.org/10.1111/j.1748-1716.2007.01757.x.

51. Ayres SM, Mueller HS, Gregory JJ, Giannelli S Jr, Penny JL. Systemic and myocardial hemodynamic responses to relatively small concentrations of carboxyhemoglobin (COHB). Arch Environ Health. 1969;18(4):699-709.

52. Ayres SM, Giannelli S Jr, Mueller H. Myocardial and systemic responses to carboxyhemoglobin. Ann N Y Acad Sci. 1970;174(1):268-93.

53. Aronow WS, Harris CN, Isbell MW, Rokaw SN, Imparato B. Effect of freeway travel on angina pectoris. Ann Intern Med. 1972;77(5):669-76.

54. Anderson EW, Andelman RJ, Strauch JM, Fortuin NJ, Knelson JH. Effect of low-level carbon monoxide exposure on onset and duration of angina pectoris. A study in ten patients with ischemic heart disease. Ann Intern Med. 1973;79(1):46-50.

55. Aronow WS, Isbell MW. Carbon monoxide effect on exercise-induced angina pectoris. Ann Intern Med. 1973;79(3):392.

56. Aronow WS, Stemmer EA, Isbell MW. Effect of carbon monoxide exposure on intermittent claudication. Circulation. 1974;49(3):415-7.

57. Aronow WS, Charter R, Seacat G. Effect of $4 \%$ carboxyhemoglobin on human performance in cardiac patients. Prev Med. 1979;8(5):562-6.

58. Aronow WS. Aggravation of angina pectoris by two percent carboxyhemoglobin. Am Heart J. 1981;101(2):154-7.

59. Sheps DS, Adams KF Jr, Bromberg PA, Goldstein GM, O'Neil JJ, Horstman D, Koch G. Lack of effect of low levels of carboxyhemoglobin on cardiovascular function in patients with ischemic heart disease. Arch Environ Health. 1987; 42(2):108-16. https:/doi.org/10.1080/00039896.1987.9935805.

60. Adams KF, Koch G, Chatterjee B, Goldstein GM, O'Neil JJ, Bromberg PA, Sheps DS. Acute elevation of blood carboxyhemoglobin to $6 \%$ impairs exercise performance and aggravates symptoms in patients with ischemic heart disease. J Am Coll Cardiol. 1988;12(4):900-9. https://doi.org/10.1016/ 0735-1097(88)90452-4.

61. Allred EN, Bleecker ER, Chaitman BR, Dahms TE, Gottlieb SO, Hackney JD, Hayes D, Pagano M, Selvester RH, Walden SM. Acute effects of carbon monoxide exposure on individuals with coronary artery disease. Res Rep Health Eff Inst. 1989;25:1-79.

62. Hinderliter AL, Adams KF Jr, Price CJ, Herbst MC, Koch G, Sheps DS. Effects of low-level carbon monoxide exposure on resting and exercise-induced ventricular arrhythmias in patients with coronary artery disease and no baseline ectopy. Arch Environ Health. 1989;44(2):89-93. https://doi.org/10. 1080/00039896.1989.9934381.

63. Kleinman MT, Davidson DM, Vandagriff RB, Caiozzo VJ, Whittenberger JL. Effects of short-term exposure to carbon monoxide in subjects with coronary artery disease. Arch Environ Health. 1989;44(6):361-9. https://doi. org/10.1080/00039896.1989.9935908.

64. Sheps DS, Herbst MC, Hinderliter AL, Adams KF, Ekelund LG, O'Neil JJ, Goldstein GM, Bromberg PA, Dalton JL, Ballenger MN, et al. Production of arrhythmias by elevated carboxyhemoglobin in patients with coronary artery disease. Ann Intern Med. 1990;113(5):343-51.

65. Sheps DS, Herbst MC, Hinderliter AL, Adams KF, Ekelund LG, O'Neil J J Goldstein GM, Bromberg PA, Ballenger M, Davis SM, et al. Effects of 4 percent and 6 percent carboxyhemoglobin on arrhythmia production in patients with coronary artery disease. Res Rep Health Eff Inst. 1991;41:1-46. discussion 47-58

66. Allred EN, Bleecker ER, Chaitman BR, Dahms TE, Gottlieb SO, Hackney JD, Pagano M, Selvester RH, Walden SM, Warren J. Effects of carbon monoxide on myocardial ischemia. Environ Health Perspect. 1991;91:89-132.

67. Chaitman BR, Dahms TE, Byers S, Carroll LW, Younis LT, Wiens RD. Carbon monoxide exposure of subjects with documented cardiac arrhythmias. Res Rep Health Eff Inst. 1992;(52):1, 26. discussion 27-37

68. Dahms TE, Younis LT, Wiens RD, Zarnegar S, Byers SL, Chaitman BR. Effects of carbon monoxide exposure in patients with documented cardiac arrhythmias, J am Coll Cardiol. 1993;21(2):442-50. 0735-1097(93)90687-V.

69. Leaf DA, Kleinman MT. Urban ectopy in the mountains: carbon monoxide exposure at high altitude. Arch Environ Health. 1996;51(4):283-90.

70. Kleinman MT, Leaf DA, Kelly E, Caiozzo V, Osann K, O'Niell T. Urban angina in the mountains: effects of carbon monoxide and mild hypoxemia on subjects with chronic stable angina. Arch Environ Health. 1998;53(6):388-97. https://doi.org/10.1080/00039899809605726.

71. Aronow WS, Ferlinz J, Glauser F. Effect of carbon monoxide on exercise performance in chronic obstructive pulmonary disease. Am J Med. 1977; 63(6):904-8
72. Aronow WS, Schlueter WJ, Williams MA, Petratis M, Sketch MH. Aggravation of exercise performance in patients with anemia by 3\% carboxyhemoglobin. Environ Res. 1984;35(2):394-8.

73. Harbin TJ, Benignus VA, Muller KE, Barton CN. The effects of low-level carbon monoxide exposure upon evoked cortical potentials in young and elderly men. Neurotoxicol Teratol. 1988;10(2):93-100. doi: 08920362(88)90072-4.

74. U.S. Environmental Protection Agency. Integrated science assessment for carbon monoxide. Final report. Washington, DC: EPA; 2010. http://cfpub.epa. gov/ncea/cfm/recordisplay.cfm?deid=218686.

75. Coburn RF. Carbon monoxide uptake and excretion: testing assumptions made in deriving the Coburn-Forster-Kane equation. Respir Physiol Neurobiol. 2013;187(3):224-33. https://doi.org/10.1016/j.resp.2013.04.006.

76. Benignus VA, Coleman TG. Simulations of exercise and brain effects of acute exposure to carbon monoxide in normal and vascular-diseased persons. Inhal Toxicol. 2010;22(5):417-26. https://doi.org/10.3109/ 08958370903576806.

77. U.S. Environmental Protection Agency. Quantitative risk and exposure assessment for carbon monoxide - amended. Research Triangle Park, NC: EPA; 2010. https://www3.epa.gov/ttn/naaqs/standards/co/data/CO-REAAmended-July2010.pdf.

78. Franck U, Leitte AM, Suppan P. Multifactorial airborne exposures and respiratory hospital admissions-the example of Santiago de Chile. Sci Total Environ. 2015;502:114-21. https://doi.org/10.1016/j.scitotenv.2014. 08.093.

79. Arbex MA, de Souza Conceicao GM, Cendon SP, Arbex FF, Lopes AC, Moyses EP, Santiago SL, Saldiva PH, Pereira LA, Braga AL. Urban air pollution and chronic obstructive pulmonary disease-related emergency department visits. J Epidemiol Community Health. 2009;63(10):777-83. https://doi.org/10. 1136/jech.2008.078360.

80. Yallop D, Duncan ER, Norris E, Fuller GW, Thomas N, Walters J, Dick MC, Height SE, Thein SL, Rees DC. The associations between air quality and the number of hospital admissions for acute pain and sickle-cell disease in an urban environment. Br J Haematol. 2007;136(6):844-8. https://doi.org/10. 1111/j.1365-2141.2007.06493.x.

81. Mekontso Dessap A, Contou D, Dandine-Roulland C, Hemery F, Habibi A, Charles-Nelson A, Galacteros F, Brun-Buisson C, Maitre B, Katsahian S. Environmental influences on daily emergency admissions in sickle-cell disease patients. Medicine (Baltimore). 2014;93(29):e280. https://doi.org/10. 1097/md.0000000000000280

82. Bathoorn E, Slebos DJ, Postma DS, Koeter GH, van Oosterhout AJ, van der Toorn M, Boezen HM, Kerstjens HA. Anti-inflammatory effects of inhaled carbon monoxide in patients with COPD: a pilot study. Eur Respir J. 2007;30(6):1131-7. https://doi.org/10.1183/09031936.00163206.

83. Tian LW, Ho KF, Wang T, Qiu H, Pun VC, Chan CS, Louie PKK, Yu ITS Ambient carbon monoxide and the risk of hospitalization due to chronic obstructive pulmonary disease. Am J Epidemiol. 2014;180(12):1159-67. https://doi.org/10.1093/aje/kwu248.

84. Camiciottoli G, Bigazzi F, Magni C, Bonti V, Diciotti S, Bartolucci M, Mascalchi M, Pistolesi M. Prevalence of comorbidities according to predominant phenotype and severity of chronic obstructive pulmonary disease. Int J Chron Obstruct Pulmon Dis. 2016;11:2229-36. https://doi.org/10.2147/copd. s111724

85. Similowski T, Agustí A, MacNee W, Schönhofer B. The potential impact of anaemia of chronic disease in COPD. Eur Respir J. 2006;27(2):390-6. https:// doi.org/10.1183/09031936.06.00143704.

86. Wheeler-Martin K, Soghoian S, Prosser JM, Manini AF, Marker E, Stajic M, Prezant D, Nelson LS, Hoffman RS. Impact of mandatory carbon monoxide alarms: an investigation of the effects on detection and poisoning rates in new York City. Am J Public Health. 2015;105(8): 1623-9. https://doi.org/10.2105/AJPH.2015.302577.

87. Lavonas E, Kerns W, Tomaszewski C, Blackwell T, Galaska P, Hay T, McCormick G, Brown A, Mott J. Use of carbon monoxide alarms to prevent poisonings during a power outage-North Carolina, December 2002. MMWR Morb Mortal Wkly Rep. 2004;53(9):189-92.

88. McDonald EM, Gielen AC, Shields WC, Stepnitz R, Parker E, Ma X, Bishai D. Residential carbon monoxide (CO) poisoning risks: correlates of observed CO alarm use in urban households. J Environ Health. 2013;76(3):26-32.

89. Vogel JA, Gleser MA. Effect of carbon monoxide on oxygen transport during exercise. J Appl Physiol. 1972;32(2):234-9. 
90. Kane LA, Ryan BJ, Schmidt W, Byrnes WC. Acute, low-dose CO inhalation does not Alter energy expenditure during submaximal exercise. Int J Sports Med. 2016;37(1):19-24. https://doi.org/10.1055/s-0035-1554641.

91. Zavorsky GS, Smoliga JM, Longo LD, Uhranowsky KA, Cadman CR, Duffin J,

Fisher JA. Increased carbon monoxide clearance during exercise in humans. Med Sci Sport Exer. 2012:44(11):2118-24. https://doi.org/10.1249/MSS. 0b013e3182602a00

Submit your next manuscript to BioMed Central and we will help you at every step:

- We accept pre-submission inquiries

- Our selector tool helps you to find the most relevant journal

- We provide round the clock customer support

- Convenient online submission

- Thorough peer review

- Inclusion in PubMed and all major indexing services

- Maximum visibility for your research

Submit your manuscript at www.biomedcentral.com/submit 